\title{
NEW SPECIES OF EXOTIC SYRPHID FLIES
}

\author{
By FranK M. HULL \\ University of Mississippi
}

\begin{abstract}
Some time ago, Professor Nathan Banks placed in my hands for study an interesting collection of Syrphid flies that had accumulated in the collections of the Museum of Comparative Zoölogy. These flies have come from many sections of the world and, as was to be expected, include a number of new species, the descriptions of which are presented in this paper. Notes on the occurrence and distribution of other species will perhaps be published at a later date. I wish to thank Prof. Banks for the opportunity of studying this interesting assortment of Syrphids as well as for the facilities for study in the Museum which he so kindly placed at my disposal.
\end{abstract}

\section{Meromacrus melmoth n. sp.}

Male. Eyes narrowly joined. Vertex slightly raised, black. Face and front black, conspicuously yellowish white pilose along the sides of the front, on the eye margins, running down the sides of the eyes and thence to the oral margin as a diagonal facial stripe. This leaves the face obscurely shining black, the black as a V-shaped wedge below antennæ, reaching to oral margin, its widest part at the base of the antennæ. Cheeks shining blackish. The facial stripe beneath the sparse pile is whitish pruinose and much more conspicuous than the pile. The pile on the sides of the front assumes the curious appressed character typical of the genus. Occiput and lower part of vertical triangle below the ocelli, similarly colored, pilose and pruinose. Face somewhat carinate. Antennæ blackish brown, the third joint lighter brown, extraordinarily truncated dorso-apically and coming to a rounded point, the arista basally thickened, yellow, quite pale at tip, and twice as long as the third joint.

Thorax, pleuræ, and scutellum dull black, except that the 
latter has a brownish rim. The markings unfortunately obscured by poor preservation but a yellow tomentose spot on the inner medial angles of humeri, a vertical narrow similar stripe on the middle of pleuræ, and some evidence of the same on the posterior calli. Halteres brownish; stalk darker.

Abdomen black, very dark brown laterally and on the posterior half of the last segment and the hypopygium, covered with microscopically short, black bristles, some scattered short pale pile, and a transverse narrow band of pale tomentum on the post border of first segment.

Legs black, tarsi brown, the femora covered with thick, quite long, pale, very fine hair. Hind femora extraordinarily thick.

Wings with a strong black anterior border, the black keeping to the configuration of the third longitudinal vein, but filling the anterior part of the first basal and the first posterior cells, and the loop of the third longitudinal vein is filled, but bears a small clear spot.

Length $15 \mathrm{~mm}$.

One male. Bolivia. Province of Sara (Steinbach). Type in the Museum of Comparative Zoölogy.

This peculiar species is very close to Meromacrus niger Sack, from which it differs in the extraordinarily thickened hind femora besides other characters. The dull black color and femora serve to distinguish it.

\section{Velocimyia n. gen.}

Small flies. Eyes bare, touching in male for a short distance. Face and front heavily pubescent and with some longer pile on the former. Face with a very low weak tubercle on bump in the middle, the lower face bluntly conical. Antennæ of the simple Eristaliform type ; arista bare, basally thickened. Thorax simple. Scutellum small, two or three times as wide as long, and without margin. Abdomen tapering posteriorward, but four segments and tip of hypogynium visible. The last segment of the abdomen together with the hypopygium wide, round, exceptionally prominent and conspicuous. In this respect the form resembles the new world Meromacrus. 
Legs except for thickened hind femora largely simple. The hind femora apicoventrally possesses a low setæ-beset tubercle. Hind tibiæ basally incised.

Wings Eristaliform. The kink of third vein is formed like that of Eristalis rather than Protylocera and there is no spur on the kink.

Genotype: Velocimyia velox, new species.

Velocimyia velox $n$. sp.

Plate II, Figs. 1, 2, 3

Male. Eyes narrowly touching for less than distance of posterior ocelli. Front, face, vertex black, the latter covered with dark brown pollen, the front with grey pubescence, the face thickly covered with white pubescence. A small shining bare space above the antennæ without trace of wrinkles. No shining median stripe on face, but an obscure bare, shining stripe on cheeks. Antennæ black, third segment grey pollinose or pubescent. Arista two and one-half times length of oval third joint, light brown in color, bare.

Thorax black, with a bluish cast, dully shining, heavily dark grey pollinose. Scutellum wide, translucent, yellowish brown, without pile, except on the corners, although its punctate surface indicates that it was pilose. Pile of thorax thick, erect, moderately long, pale in color. Squamæ and fringe pale yellow, very large. Abdomen with venter and hypopygium entirely bright orange with one exception. The base of the second segment with a broad basal triangle, its apex reaching less than one half of the length of the segment, the triangle continued to the first segment, where it is bluish black, leaving only the lateral corners of that segment pale. Abdomen practically opaque except for the last segment. Last two segments and third and fourth with parallel sides, narrower than the second. Hypopygium very large. Pile of abdomen pale, rather long terminally.

Legs black, base of face and mid tibiæ yellowish brown, mid basitarsi dark brown. Hind femora very thick, but confined to anterior surface, posterior surface straight, a nodular prominence beset with bristles near the apex. Hind tibiæ opposite nodule of femora noticeably incised, its apex spurred. 
Wings hyaline, stigma brown. A deep loop of third longitudinal vein into first posterior cell; the marginal cell closed before the apex of first longitudinal vein, and the first posterior cell closed before apex of third longitudinal vein.

Length $10 \mathrm{~mm}$.

Three co-types. Males. One is from Mandritsara, Madagascar (Wulsin) whose type no. is 2270 in the Museum of Comparative Zoölogy. The two others, Antananarivo, Madagascar, were discovered in the collections at the $\mathrm{Mu}$ seum für Naturkunde, Berlin. Dr. G. Enderlein has kindly presented me with one of them, which is in my own collection. The third is in his collection.

The first specimen studied, from the Museum of Comparative Zoölogy, curiously bears no evidence of the spotted eyes, and I was inclined to view this species as nearest to Protylocera. The discovery of subsequent specimens reveals that the eyes are generously spotted. Nevertheless, the distinctive type of abdomen, much enlarged hypopygium, as well as the excised tibia and nodulate hind femora show that it is not an ordinary Lathyrophthalmus. Another species which Speiser placed under Lathyrophthalmus, myiatropinus, agrees in these peculiarities and differs from the present species in its dark terminal segments, etc. The two forms may very well be grouped under the name given, since besides the other distinctions mentioned, they lack either the metallic color or the characteristic stripes of Lathyrophthalmus. It may be remarked that the spotted nature of the eyes probably shows no close relationship to Lathyrophthalmus whatever, since at the present no less than five genera show such spots. Three genera show the enormous hypopygium: Meromacroides of Curran (Africa), Meromacrus Rondani (S. America) and the present group of species.

Lathyrophthalmus vitrescens $\mathrm{n}$. $\mathrm{sp}$.

Plate II, fig. 4

Female. Eyes distant by one and one-half times width of posterior ocelli; side of front diverging considerably towards antennæ. Front yellow and grey-brown pollinose, varying according to direction, but apparently with a con- 
stant, pale, narrow eye stripe, a large pale region above antennæ surrounding a brown central elevation. Middle of lower front with a narrow dark brown streak. Face with pale yellow brown pubescence, except for bare central knob. Face rippled. Antennæ light or orange brown, darker dorsally on third joint. Arista very long, pale brown. Cheeks more or less bare shining light brown. Eyes spotted, of which it may be said that the spots are very numerous, small, mostly regularly spaced, rarely confluent, and usually separated by from one to two times their own diameter.

Thorax blue black, shining, five vittate, the vittæ dull grey but being obscurely shining posteriorly. Scutellum strongly shining greenish blue. Squamæ dark brown, halteres lighter.

Abdomen shining, greenish or bluish black, except that the first segment and base of second is dark brown, and the second, third and fourth segments are crossed by opaque black bands, first barely interrupted, the latter two well interrupted medially and laterally.

Legs dark brown, apices of femora very narrowly, basal half or third of tibiæ, and all the tarsi light yellow or brownish yellow, palest on the tibiæ. Wings very hyaline. Stigma quite small.

Length $12 \mathrm{~mm}$.

One female. Fiji; Lomoti. (W. M. Mann.) Type in the Museum of Comparative Zoölogy.

I should be inclined to place this species in L. nitidus .Wulp, did not specimens I have seen from Samoa agree better with the notes and interpretation of the species by Herve-Bazin and Bezzi. These I have commented on in my paper on Samoan Syrphidæ. The more totally blue black coloration, entire opaque bands of abdomen, and minor differences convince me that the two forms are at least quite different species.

Korinchia simulans de Meij.

Originally described by de Meijere as a Milesia, but should probably be placed in Korinchia.

Two females in the Museum of Comparative Zoölogy. Java; Tijboda (T. Barbour).

Eumerus obtusiceps n. sp.

Male. Eyes touch for the short length of front. Vertical 
triangle is therefore long, acute in front, its sides parallel behind. Occiput remarkably thick, pale brownish polinose, black punctate. Vertex similarly pollinose and punctate, anterior ocelli far removed, lying in brown pollen, the posterior pair in a black area. Eyes bare. Pile of the vertex largely blackish except just in front. Front and face covered with brilliant silver scalose pubescence and some erect white pile. Occiput punctate white scalose, short white pilose. Antennæ situated slightly below middle, black. Third joint large, ventrally pointed. Arista basally thickened, yellow, remainder very wiry, slender and dark.

Dorsum of thorax black, obscurely shining, thickly punctate, pile short, thick, black with some pale hairs, the suture narrowly pale whitish or greyish pollinose. Scutellum concolorous, flat, its edge with a conspicuous narrow yellowish brown pollinose border, its apex with outwardly directed short pile of the same color, and its erect surface pile longer than that of the thorax and entirely pale. Moreover, the bulk of the pile is also on the rim and directed upward at an angle of forty-five degrees. Squamæ and halteres brownish yellow.

Abdomen decidedly flared basally; abdomen shining black, thickly black punctate, bearing thick appressed black bristles most prominent on terminal segment, and considerable fine white pile, particularly on the sides of the abdomen. First segment with a narrow $\mathrm{V}$ of white punctate pollen, barely interrupted medially, the angle anteriorly directed, and the ends continued (narrowly)into the corners of the third segment. Third segment similarly marked, and fourth similar except that the pollinose spot spreads out posteriorly and is largely broken by black punctate spots. Fore and middle legs brown, apices of the femora, of the tibiæ and their base and all the tarsi brownish yellow. Hind femora and tibiæ black, except narrow apex of former, and base of latter; both thickened, the femora greatly enlarged. Hind tarsi brown, basi tarsi greatly dilated.

Wings with terminal segment of fourth longitudinal vein oddly angulated, just before reaching the third longitudinal vein, it forms an acute $\mathrm{V}$-shaped angle; the angle of the $\mathrm{V}$ is spurred. Wings slightly fumose.

Length $8.5 \mathrm{~mm}$. 
One male. Neumannis Boma, British East Africa (Allen and Brooks). Type in the Museum of Comparative Zoölogy.

This species traces to Eumerus scaber in Bezzi's key. That species is said to have a bare bluish front; its genitalia are reddish. The occiput of this species cannot be described as black pilose, etc. In Herve-Bazin's key it traces to Eumerus fere Bez. with which it could hardly be confused.

\section{Microdon argentinae n. sp.}

Plate II, fig. 5.

Male. Front narrowed sharply above antennæ. The narrowest width slightly better than one-half width at vertex measured from upper eye angles. The narrowest portion marked by a prominent groove on its front side obtusely widened and leading down to a point between antennæ. Front and vertex and face rich shining brown. Cheeks a little darker brown. Face strongly convex, both from the side and from above. Vertex slightly raised. First joint of antennæ light shining brown, as long as front from vertex to depression. Remainder of antennæ wanting. Pile of face and head everywhere pale yellow, sparse, shorter on the front, rather long and thicker on the sides of face below antennæ. Middle of face nearly bare, possibly due to denudation.

Dorsum of thorax, pleuræ, scutellum, and legs rich shining brown, the abdomen pale brown. Pile of thorax short, pale, appressed, with a few scattered darker hairs. Scutellum quite wide, trapezoidal, the small but slender, sharp, bare points, quite far apart, slightly diverging. Middle of scutellum not emarginate. Halteres dark brown.

The abdomen is of the short broad form, pointed apically, with ventral flexure at the edges of the flared second segment.

Piles of legs dark brown, becoming golden brown on lower surfaces of tarsi and apical portions of tibiæ. Hind basitarsi not remarkably thickened, its greatest thickness basally, twice its distal thickness, perhaps a little more than twice as thick as the second tarsal segment.

Wings tinged rather uniformly with brown. Veins dark brown. Last section of fourth longitudinal vein very angulated, emitting a stump on each side toward margin of wing, 
and trace of an inward stump on one wing. Lower terminal section of vein closing first posterior cell and one closing discal cell remarkably rounded. An extensive spur is present from the third longitudinal vein almost reaching spurious vein.

Length $10.5 \mathrm{~mm}$.

One male, Cordova, Argentina (Davis). Type in the Museum of Comparative Zoölogy.

\section{Microdon digitator $n$. sp.}

\section{Plate II, fig. 6.}

Male. Head rounded in profile; similar to Microdon investigator. Front narrowest above antennæ, but the sides nearly parallel, diverging toward the vertex. Antennæ, face, front and vertex black, the latter shining. Antennæ short, the first joint and third subequal, either twice the length of second. Arista short, much thickened basally, reaching just past third joint. Pile of head everywhere pale yellowish to whitish, sparse.

Thorax and scutellum everywhere shining black. Pile sub-appressed, sparse, yellowish to golden. Scutellum evenly rounded, a little more pointed centrally, without spines, margins, déntations, etc. Halteres brown.

First and fourth abdominal segments brown to black, obscurely shining; second and third pale brownish yellow, the second the palest, subtranslucent. Pile very short except on the outer edges of the second segment where it is long and golden. Pile black or brown elsewhere, except on the posterior lateral angles of the third segment where it is golden. Legs light brown except for the middle of all the femora, and quite small spots in the middle of each tibiæ. Hind basitarsi not at all thickened.

Wings rather uniformly suffused with brown, lighter in the first posterior, discal, first basal cells. Termination of fourth longitudinal vein straight, nearly rectangular, angle of discal cell rounded. Spur of third longitudinal present, spurious vein not prominent. Angle of first posterior cell spurred to near by wing margin.

Length $9 \mathrm{~mm}$.

One male, Tjibodas, Mt. Gede, Java. 1909, 4500 ft. (Bry- 
ant and Palmer). Type in the Museum of Comparative Zoölogy.

Microdon investigator $n$. sp.

Plate II, fig. 7 and 8.

Male. Sides of front nearly parallel, slightly converging to vertex, narrowest just across ocelli. Front smooth, shining brownish black, punctate. Antennæ situated just below upper point of middle third of profile. Profile of head evenly rounded, remarkably convex. Cheeks very narrow, invisible in profile. Face widest just below antennæ. Sides nearly parallel. No antennal prominence. Antennæ light orange, first joint twice length of second, third equal to first and second concave dorsally, drawing out to a sharp point, suggesting a thumb. Arista pale, slightly longer than third joint. Face shining brassy brown, with a suggestion of violaceous color. Pile of face, front, vertex sparse brassy yellow, appressed on face.

Thorax and scutellum dark, moderately shining brown, pile golden, thick and markedly appressed. Pleuræ similarly colored with a conspicuous patch of dense golden pile. Pile of scutellum erect. Squamæ and halteres light yellow.

Abdomen pale yellowish brown, third and fourth with basal halves and nearly the whole of the fifth segment dark brown. Pile of light area exceptionally dense and appressed, golden; of dark area black. Venter pale brownish yellow, sub-translucent, the lateral edges continuously black.

Legs light brownish yellow, except for a dark brown spot about the middle of antero-ventral surface of each femur and the basal third of the tibiæ, paler yellow. Hind femora with anterior diagonal scar or cicatrix on basal half. Hind basitarsi nearly as long as remaining segments inclusive; twice their thickness.

Wings palely but uniformly brownish; termination of fourth longitudinal vein sharply rectangular, its angle emitting a spur; an angle of discal cell rounded. Spurious vein quite faint. Spur from third longitudinal vein prominent.

Length $13.5 \mathrm{~mm}$.

One male, Galog River, Mt. Apo, Mindanao, Philippine 
Islands, Sept. 12 (C. S. Clagg). Type in the Museum of Comparative Zoölogy.

Hypselosyrphus n. gen.

Plate II, fig. 9.

Small flies, related to Microdon with the weak and flattened abdomen somewhat longer than broad. Face round convex, with the vertex produced into a curved jutting knob. Scutellum sulcate, tumid, angularly directed upward. Hind basitarsi and forebasitarsi swollen. Hind tibiæ convex, with a swollen ornament suggesting a load of pollen, heavily pilose. Hind femora not greatly thickened. No trace of spur from third vein is directed into the first posterior cell. Terminal (bent up) portions of fourth and fifth longitudinal veins, that is, subapical and posterior cross veins, nearly straight, bulging at their basal corners and making angles of approximately seventy-five to eighty degrees with the veins they join.

Genotype: Hypselosyrphus trigonus n. sp.

This fly suggests very strongly a trigonid bee, as do the species of Ubristes of the Microdontini. Microdon scutellaris Shannon, described from the Amazon, seems to fall into Hypselosyrphus, but differing in the differently colored abdomen.

\section{Hypselosyrphus trigonus $\mathrm{n}$. sp.}

$$
\text { Plate II, fig. } 9 .
$$

Male. Front enormously swollen as a shining knob, the ocelli on top. Front excavated, flat, leaving a considerable concavity in profile. Face in profile convex, evenly rounded. Antennæ situated at upper third. First and third joints subequal, the latter pointed, second quite short. Arista slender, as long as third joint. Color of antennæ dark brown. Face, front and vertex shining dark mahogany red or brown, almost black.

Thorax very dark brown, almost black, a row of white pile across at suture, and on base of scutellum, remainder densely erect short black pilose. Pleuræ shining dark brown, sparsely pilose. Halteres and squamæ dark blackish. Scutellum dark blackish, prominent, directed upward at an 
angle of forty-five degrees, deeply sulcate medially, the sides swollen, rounded, without spines.

Abdomen short oval, flat, vitreous, dark reddish brown on first, second and narrowly on base of third segment. Remainder bright orange.

Legs dark shining purplish or reddish black, tarsi except hind basitarsi light yellowish brown. Fore basitarsi swollen anteriorly. Hind basitarsi considerably swollen. Hind tibiæ greatly swollen and dorsally arcuate, a curious crease running around it, below the part of greatest swelling. Tibiæ heavily long black pilose.

Wings brownish especially basally, with a faint pale yellow spot beginning past the stigma. Last section of fourth longitudinal vein straight, not angular, no spurs present, not even from the angle of the fourth longitudinal vein.

Length $7 \mathrm{~mm}$. or about $8 \mathrm{~mm}$. with the antennæ.

One male. Barro Colorado, Panama, July 16, 1924 (Nathan Banks). Type in the Museum of Comparative Zoölogy.

This remarkable species suggests Microdon panamensis Curran, which lacks the interesting structural characters of this form. It is a handsome and peculiar species, that like Ubristes resembles Trigonid bees, but differs from that genus in the development of the vertex and scutellum, etc.

\section{Paramicrodon novus n. sp.}

Plate II, figs. 10 and 11.

Female. Head very globular, front wide, almost horizontal, sides nearly parallel diverging slightly to vertex. Vertex from corner of eyes very suddenly and sharply widened so that the post optical vertex is wide and deep. Front and vertex slightly convex, their color shining brownish or black, with short abundant, upright, golden pile. Ocelli set far down the middle of the front, more than half way down from vertex (extreme) to antennæ. Face more narrow than front, sides almost parallel, similar in color and similarly pilose. Antennæ set a little above middle of face, wholly brownish orange, first and second joints short, subequal, third equal to first and second. Arista dark, thickened basally, half again as long as third joint. Eyes bare. 
Thorax shining brown, slightly brassy, covered with dense golden pile, highly appressed, a vertical pilose band on the pleuræ. Scutellum brown, simple. Margin evenly rounded, surface but little convex. Halteres and squamæ brownish yellow.

Abdomen dark brown, base of first segment with a yellow band, incised on its posterior border, a convex yellow band on the posterior border of second segment, a narrow similar border on the posterior edge of third segment and the narrow corners posteriorly of fourth and extreme tip of fifth segments. The posterior margins of second, third, fourth and fifth segments with a fringe of thick long, appressed golden pile. Abdomen quite elongate, over twice the length of thorax. Second segment nearly as long as third and fourth; fifth segment almost as long as fourth. Third and fourth segments subequal. Abdomen but little, if at all, constricted basally.

Legs light brownish yellow, golden appressed pilose, a brownish median band on the hind femora, a trace of same on mid femora.

Wings quite elongate; first posterior cell five to six times as long as wide at widest point. Third longitudinal vein without protruding spur. Spurious vein faint. Wings uniformly pubescent, tinged with pale brown.

Length $13.5 \mathrm{~mm}$.

One female. Galog River, $6500 \mathrm{ft}$. Sept. 12, Mt. Apo, Mindanao, Philippine Islands (C. S. Clagg). Type in the Museum of Comparative Zoölogy.

This species must certainly be very close to Herve-Bazin's genotype, Syrphinella miranda H. B. Nevertheless, a careful comparison of the specimen before me with his very excellent figure, shows this form to have the third antennal joint a little shorter, the body narrower at base or more spatulate, and there are a fused pair of sub-translucent windows at the base of the second segment. The posterior golden pilose band of the fourth segment appears widely interrupted in novus (and there is in fact no light colored ground color), though it may be denudate. The wings are less generally infuscated, being really darkened only about the extreme tip. The veins over the wing are clearly not margined with brownish. I have seen other specimens from 
the Philippines agreeing with Herve-Bazin's figure of Syrphinella in that the veins are markedly infuscate. Moreover they agree in the lack of translucent window to abdomen, and in having the fourth abdominal segment yellowish posteriorly and more or less golden pilose over the whole width. Thus they are very close to Syrphinella if not identical. But they have the third antennal joint distinctly pointed. P. novus, and the figure of miranda in nowise agree in this particular. De Meijere has described three other species in this genus from Java, New Guinea and Borneo, so that there may be many species. Sack has described what is probably a synonym of miranda under the name Mixogaster cinctella Sack.

\section{Paramicrodon delicatulus n. sp.}

This species differs from Microdon flukei Curran in the general bluish purple color, as well as other particulars. Pile above antennæ on vertex and occiput silvery, narrowly black below ocelli in the front. The antennæ are wholly orange, whereas they are brown in flukei with a black third joint. Abdomen unicolorous purplish, with the basal red color of flukei.

Two males. Soledad (Cienfuegos), Cuba, August 6, 1920 (N. Banks). Type in the Museum of Comparative Zoölogy. Paratype in the author's collection.

\section{Pseudomicrodon n. gen.}

Head short to quite short. In profile, occiput above moderately or considerably thickened. Antennæ situated above the middle of the head in profile, quite elongate in form. The first joint about as long or longer than remaining two, though obviously proportions in length must vary over some latitude in Microdontine antennæ. Face gently convex. Cheeks inconspicuous. Vertex rarely protuberant. Abdomen rather strongly pedunculate; the segments after the second fused into a beautiful, oval, cylindero-convex body, which is widest on the fourth segment, rounds off posteriorly, tapers gently forward anteriorly, and is strongly flexed downward at the second segment, practically held at right angles. Scutellum usually bears two fairly well developed teeth or points. Hind femora usually only moderately thick- 
ened. First posterior cell with an adventitious vein, the subapical cross vein is straight.

Genotype: Microdon beebei Curran.

I have seen a number of species which fit with tolerable accuracy and certainty into the concept above; among them may be mentioned Microdon nigrispinosis Shannon, illucens Bezzi and probably bellula Williston.

\section{Ceriomicrodon n. gen.}

Head in profile not very long but extremely wide, practically twice as wide as thorax between the humeri. Occiput and vertex moderately developed, in nowise conspicuous. Front and face of average width. In profile the face bulges out below, much as in Rhopalosyrphus Gig.-Tos. Antennæ quite elongate, the third joint quite wide and flat and about two and one-half times as long as the first joint. Eyes bare on either side opposite antennæ with a curious narrow crease margined with grossly enlarged facets. This may be an abnormality, but as it is perfectly symmetrical on both sides, it may be normal. Occipital fringe reduced to a single row of long collar like hairs, much as in Asarcina or Baccha. Abdomen extremely petiolate, the first segment small, apparently completely fused with second segment, at any rate the first and second segments together are nearly ten times as long as wide in the middle. The second segment expands on its extreme posterior edge rather suddenly to some three or four times its narrowest width. Remaining segments fused into an oval bulging club. Scutellum quite short, broad and rounded, without spurs. Wings with a spur descending into the first posterior cell. Angles of the first and second posterior cells broadly rounded, without a trace of spurs.

Genotype: Ceriomicrodon petiolatus n. sp.

Cerioimicrodon petiolatus $n$. sp.

Face pale yellow, a wide median stripe, the cheeks, front, vertex, dorsum of thorax and scutellum fully shining bluish black. Abdomen obscurely shining black, second segment sub-translucent yellowish brown. Pile of thorax and dorsum microscopically short, save for white flecky pile on 
transverse suture and at junction of third and fourth abdominal segments.

One male. West border Matto Grosso, Brazil, May, 1931 (R. C. Shannon). Type in the U. S. National Museum.

Stenomicrodon n. subgen.

Head in profile not especially long, the occiput above not more than normally developed, the front quite flat, of moderate width. Ocelli in a small, nearly equilateral triangle. Antennæ situated near the top of head, elongate, first joint at least as long as remaining joints. Cheeks inconspicuous and eyes bare. Abdomen elongate, several times as long as wide. The first segment flattened and excavated on each side. A deep constriction at the junction of the third and fourth segments and in the female slightly between the fourth and fifth segments. Scutellum without spines. Femora slightly thickened, with more than usually strongly developed patches of bristly setæ on the base of the third femora in both sexes as well as on the others. This extensive setiferous patch is quite differentiated from the surrounding pile. Third vein sends an adventitious vein down into the first posterior cell. Corners of first and second posterior cells broadly rounded, without spines apically. Wings in the known species are dark purplish brown.

Subgenotype: Stenomicrodon purpureus n. sp.

\section{Stenomicrodon purpureus $\mathrm{n}$. sp.}

Differing from Microdon stenogaster Curran in the thicker third antennal joint, silvery pile, deeper scars on the hind femora and lighter colored pile.

One female, Tainan, Formosa (Rolle). Type in the author's collection.

\section{Oligeriops n. gen.}

Head very broad from above; vertex enormously developed. Ocelli situated on the summit in an equilateral triangle. Front in consequence quite broad, deeply punctate, eyes reduced in size, bare; cheeks bulging, together with the wide, slightly diverging face, densely long pilose. Head in profile more or less smoothly and evenly round. Antennæ set about the middle. First and third joints elongate, the 
latter thick, particularly so at base, on its upper surface curved, with a short massive arista. Abdomen broad, oval, about one and one-half times as long as broad. The margins of the segments rolled, but in no way massively developed. Terminal portion of abdomen fused, gradually rounded, curved downward, the sides particularly convex towards the tip. Scutellum without points. Hind femora moderately thickened, femora and tibiæ without cicatrices or furrows. Subapical crossvein erect, almost straight, meeting the third vein at right angles quite far back from the margin. First basal cell with an adventitious vein descending into first posterior cell.

Genotype: Microdon chalybeus Ferguson.

Papiliomyia n. gen.

Head hemiglobular in profile, post occiput above tumid and vertex protruding as a conspicuous bump, but otherwise the front and vertex are quite narrow. Ocelli situated at top of the protuberance. Antennæ situated near top of head, the first joint quite elongate, in fact being considerably longer than remaining two together. Arista weak and delicate. Face narrower from the front, converging from below the antennæ. Eyes bare. Cheeks practically absent. The enormous eyes seem to cover almost the whole head. Abdomen elongate, over two times as long as wide. Widest at junction of second and third segments, but very little wider here. Fourth segment most deeply transversely concaved as far as the anterior two-thirds, leaving a convex rim posteriorly. The concave portion most oddly covered with centrally converging, flat lying hair from the base and sides. Metanotum exceedingly conspicuous and deep. Scutellum without points. Hind femora slender, basally spindled. Hind tibiæ thickened apically and with a deep shallow groove separating the apical fifth. Hind tibiæ very brushy as in Trigonoid bees. Wings long and slender. No trace of adventitious veins descends into the first posterior cell. Subapical cross vein straight and recurrent as well. Postical cross vein sigmoid in the genotype species. Costa deeply beaded with setigerous tubercles. Wings banded in both the known species. Weakly chitinized, delicate species, that suggest moths or scorpion flies. 
Genotype: Papiliomyia sepulchrasilva n. sp.

\section{Papiliomyia sepulchrasilva n. sp.}

Differing at once from Microdon maculatus Shannon in the possession of only a single basal wing spot; apical half of thorax largely yellow, with two round spots and a wedge shaped spot; posterior half with two L-shaped spots. Abdomen past second segment almost wholly dark. Yellow wing border extended across wing as a stripe.

Two males. Rio Grand do Sul (Stieglmayr). Type in the Natural History Museum of Vienna. Paratype in the author's collection.

\section{Syrphus cinereomaculatus $n$. sp.}

Plate II, fig. 12.

Female. Front rather wide, nearly twice as wide at antennæ as at vertex, with the slightly raised vertex shining black, long blackish pilose, a dull grey pilose spot in the shallow depression of front, on either side about midways. Antennæ black. First and second subequal, the third three times as long as first, decidedly pointed at outer dorsal end. Arista black, thickened on basal two-thirds; no longer than the third joint. Face with a small shining black bare tubercle, gently concave beneath antennæ. Cheeks brownish, white pollinose, with a small bare diagonal stripe. Face heavily pollinose. Occiput to just above middle, long white pilose, thickly so. Pile of face long, thin, white, a conspicuous tuft before wing base. Scutellum yellowish brown, very shining long sparse black, pilose. Squamæ nearly white, tinged with brown, bare on lower lobe surface. Plumula snow white, halteres dark brown; knob paler.

Abdomen oval, shining black, a band on second segment interrupted in middle, quite narrow bands on third and fourth, narrowly interrupted in middle, are noticeable only for the gray pollen which covers them, though careful examination shows the underlying surface to be dark brown. Traces of smaller narrow spots are on the fifth segment. Abdomen very flat, emarginate. Venter shining black, with obscure grey pollinose bands.

Legs with the femora black, except the narrow yellow or 
brown apices, white pilose. Tibiæ yellowish brown, darker in the middle. Tarsi dark brown to black. Hind femora very slender. Wings quite hyaline, stigma yellow, with proximal brown spot.

Length $9.5 \mathrm{~mm}$.

One female. Mt. Kenia, British East Africa, Sept. 8 (G. M. Allen and G. Brooks). Type in the Museum of Comparative Zoölogy.

This interesting species is characterized by the highly vitreous black color, flat abdomen, remarkably narrow, slender grey pollinose bands or spots.

\section{Pipunculosyrphus n. gen.}

Head hemispherical. Eyes very large. Vertex small, compressed until knife like, the anterior ocellus not much remote and the vertex not swollen. Occiput narrowly visible in profile, except near the top, its collar of hairs short, but conspicuous, single rowed, and Baccha-like. The eye margins strongly concave in the middle, their facets enlarged above in the male. Antennæ set in middle of head in profile. Short, third joint orbicular. Arista slender, longer than the antennæ. Front swollen, face below antennæ rather concave, tubercle conspicuous, abruptly rising and declining. Face retreating past the tubercle. The cheeks inconspicuous. Sides of face parallel and close together. Thorax slightly longer than broad, convex. The humeri hidden by the head, bare. The mesopleuræ and dorsum practically without pile. Scutellum is long with long bristles on its rim and a ventral fringe is present.

Abdomen long and slender, about five times as long as wide with parallel sides. First segment short, laterally inflated and strongly convex. Its extreme base equipped with a vertical fringe of erect hairs against the metanotum which is inconspicuous. Abdomen dark with yellow bands or pairs of spots. Hind femora very slender and long. Hind tibiæ equally slender, not quite as long. The basi tarsi more than half as long as tibiæ. The mid femora flattened basally. Wings very elongate, being more than three times as long as wide. Alulæ absent. The marginal cross veins quite sigmoid. Vena spuria prominent.

Genotype: Pipunculosyrphus globiceps n. sp. 
I consider this genus to be amply well founded since it represents an extreme as far as the known species are concerned, in at least four or five particulars. Unrelated to Baccha to which it bears a superficial resemblance, but it is noteworthy in the enormous eyes, hidden humeri, narrowly reduced face, knife-like vertical triangle, the shortened non-petiolate, abdomen, exceedingly elongate wing and lost alulæ, to say nothing of the erect basal metanotal fringe.

Pipunculosyrphus globiceps n. sp.

A slender light yellowish fly, which is brown on the upper part of the third antennal joint, upper half of front, disc of thorax, hind femora except basally, and the abdomen, except for pairs of yellow spots which are bordered by black. Front with a small round black spot above antennæ. Vertex black, paired spots of abdomen obliquely directed forward, their black posterior borders like confluent V-shaped marks. Last segment vitate. The middle stripe broad and black. Wings pale brownish. Stigma a little darker.

Two males, San Bernardino, Paraguay (Fiebrig). Type in the Museum of Natural History, Vienna, paratype in the author's collection.

Oligorhina $n$. gen.

Eyes bare, the vertex narrow, rapidly widening to the level of the antennæ, where the face is parallel-sided and rather narrow. In profile the head slants down from the vertex quite straight to the low tubercle shortly below the antennæ and is then still further produced to the epistoma, though not quite so sharply. Face, because of the narrowness, with a pinched out aspect. Antennæ set very far apart, short. The third joint a little longer than wide. Arista as long as the antennæ. Occiput not visible from the side below the middle of the eyes. Thorax as wide as head, quite convex, both from the front and from the side very sparsely pilose. Humeri bare, scutellum large, semicircular, somewhat flattened, a few large bristles on the margin, a few downward projecting hairs, but scarcely any fringe. Abdomen slender, spatulate, about five times as long as its greatest width, which begins on the fourth segment. Fourth and fifth segments with practically parallel sides. Second seg- 
ment apically about two-thirds as wide as the fourth segment. Sides of the short first segment convex with stiff bristles. Margins of the abdomen curling over, especially posteriorly, where they decrease the width some. Femora short, straight, scarcely thickened. Tibiæ distally a little thickened and a little pinched, every bit as long as the femora. Wings considerably longer than abdomen. Alulæ reduced. Subapical cross veins close to wing margin, but very sigmoid. Third vein and costa carried down somewhat deeply at the end of the wing. Vena spuria heavily chitinized. Stigma dark.

Genotype: Oligorhina anea n. sp.

\section{Oligorhina aenea n. sp.}

A curious species characterized by the very brown wings, darkened apically with a dark brown stigma. The rusty orange front, the black spot above antennæ and facial strip black. Vertex bright yellow, pleuræ, humeri, sides of pronotum calli, scutellum and anterior pairs of legs and the base of hind femora. The cheeks pale brownish yellow, the sides of the face bright shining yellow. Abdomen reddish brown, basal and apical borders of the remaining segments broadly shining, but preceded by opaque bands, which are produced forward as a slender triangle as far as the base of the segment.

Two females. Desbarriere, Mt. La Hotte, Haiti (4000 ft.), October 12, 1934 (Darlington). Type in the Museum of Comparative Zoölogy. Paratype in the author's collection.

\section{EXPLANATION OF PLATE II}

1. Velocimyia velox n. sp. (abdomen)

2. Velocimyia velox n. sp. (hind femora)

3. Velocimyia velox n. sp. (wing)

4. Lathyrophthalmus vitrescens n. sp. (abdomen)

5. Microdon argentinæ $\mathrm{n}$. sp. (wing)

6. Microdon digitator n. sp. (antennæ)

7. Microdon investigator $\mathrm{n}$. sp. (antennæ)

8. Microdon investigator (wing)

9. Hypselosyrphus trigonus n. sp. (profile of head; 9 a is scutellum)

10. Paramicrodon novus n. sp. (wing)

11. Paramicrodon novus n. sp. (profile of head)

12. Syrphus cinereomaculatus n. sp. (abdomen) 

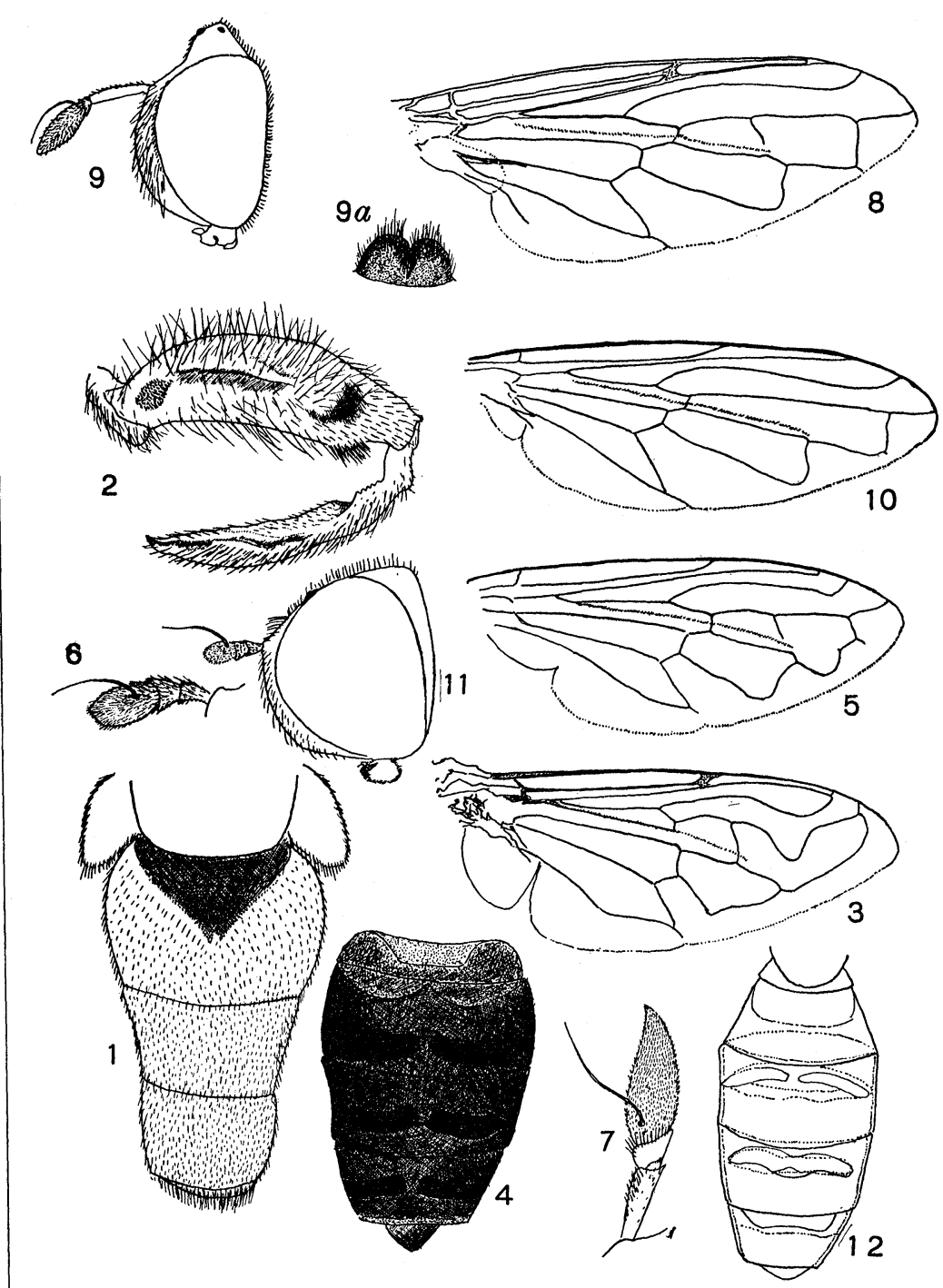

Hull - Syrphid Flies 

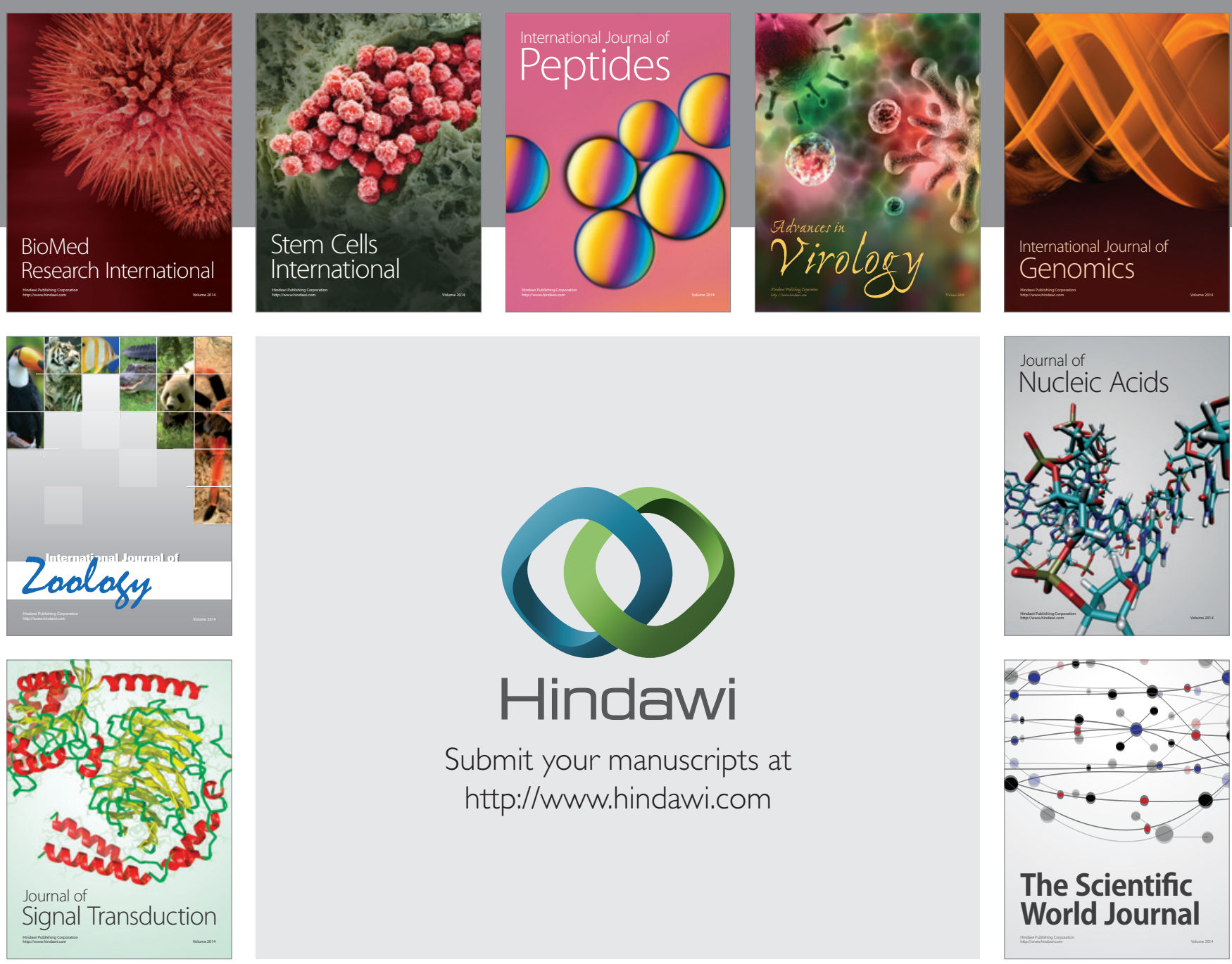

Submit your manuscripts at

http://www.hindawi.com
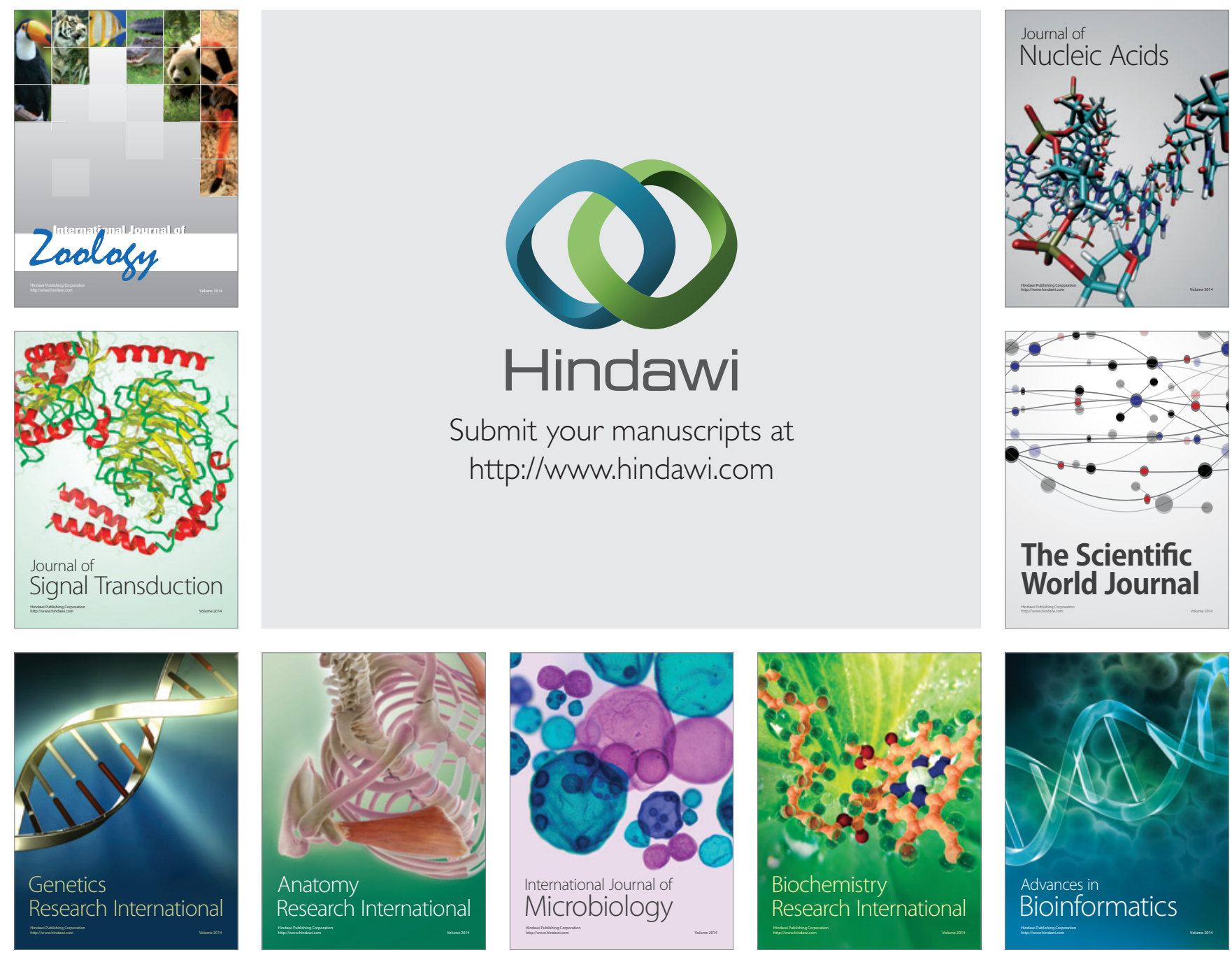

The Scientific World Journal
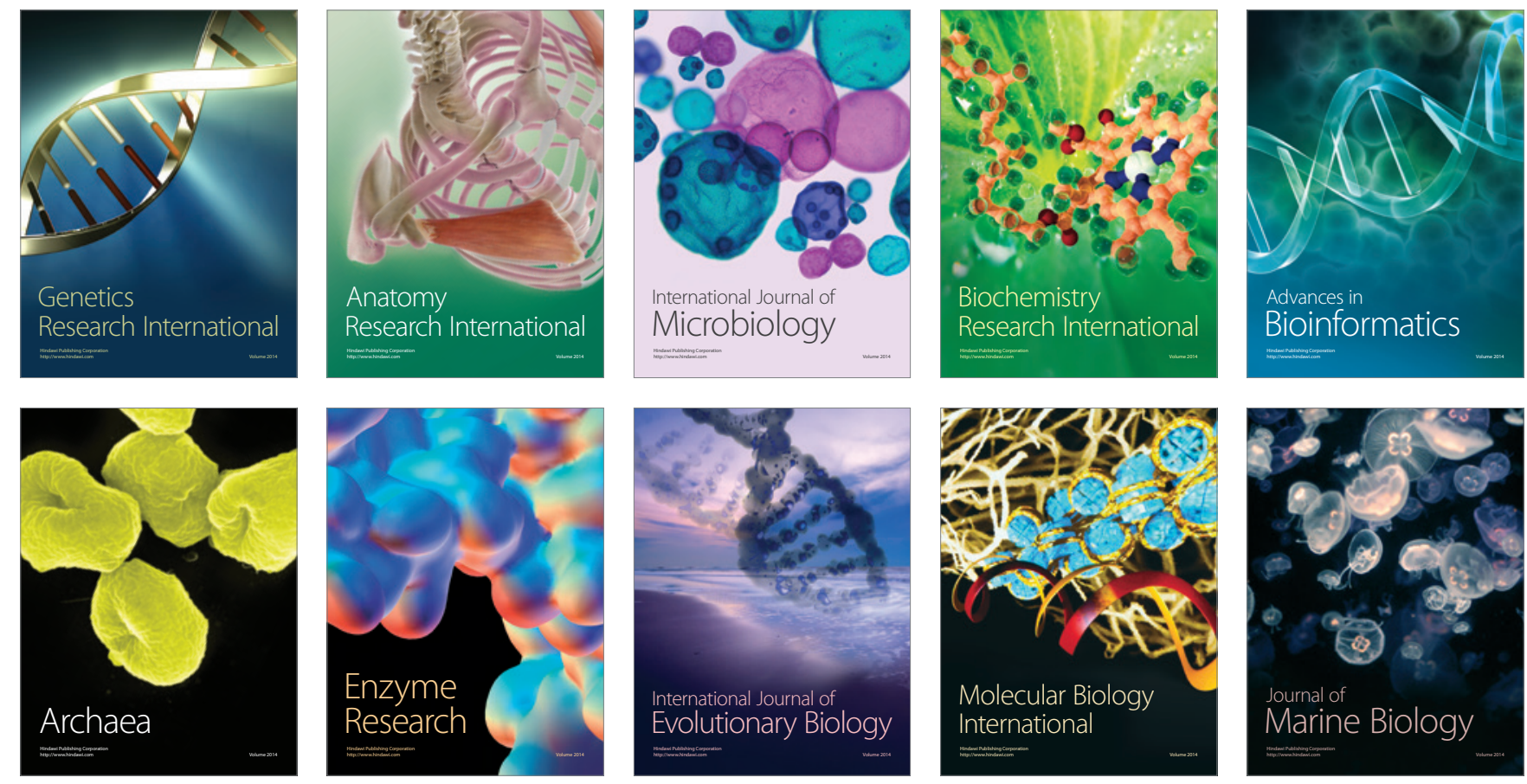